\title{
URGENSI PENDIDIKAN AGAMA HINDU BAGI ANAK
}

\author{
Oleh \\ Ida Ayu Adi Armini \\ (Dosen Jurusan PGPAUDH IHDN Denpasar)
}

\begin{abstract}
Education is an effort to realize the growth of the character of the child (inner strength, character, mind or intellect) and the child's body to refer to the child's life in harmony with his world. But in the present era that is full of things that degrade the side of humanism. Education should give birth to the children who have good character, just the contrary gave birth to people who behave badly. Psychological touch is rarely found in education today. It is rooted in the application of education in which there are models and processes without touching the side of humanism itself, so the application of education is only a mere formality. Consequently, children were born intelligently good but spiritually less. Many children are smart, but few have good character. This is where the importance of religious education as a role synergized.
\end{abstract}

\section{Keywords : Urgency, Hindu Religious Education, Children}

\begin{abstract}
Abstrak
Pendidikan adalah sebagai daya upaya untuk mewujudkan tumbuhnya budi pekerti anak (kekuatan batin, karakter, pikiran atau intelek) dan tubuh anak itu untuk mewujukan kehidupan anak yang selaras dengan dunianya. Namun di era sekarang yang penuh dengan hal-hal yang mendegradasi sisi humanisme. Pendidikan yang seharusnya melahirkan anak yang memiliki karakter baik, justru sebaliknya melahirkan manusia yang berprilaku buruk. Sentuhan psikologis jarang ditemukan dalam dunia pendidikan dewasa ini. Hal tersebut berakar pada diterapkannya pendidikan yang didalamnya ada model dan proses tanpa menyentuh sisi humanisme itu sendiri, sehingga penerapan pendidikan hanya bersifat formalitas semata. Akibatnya lahirlah anak-anak yang cerdas secara jasmani namun kering secara rohani dan spiritual. Banyak anak pintar, namun sedikit yang berkarakter. Disinilah pentingnya pendidikan agama sebagai role yang mensinergikan.
\end{abstract}

\section{Kata Kunci : Urgensi, Pendidikan Agama Hindu, Anak}

\section{PENDAHULUAN}

Masyarakatumum sering mendengar kata pendidikan dan kadang kala seseorang mendengar kata pendidikan maka secara spontan kata tersebut dihubungkan dengan sekolah. Anggapan ini bukanlah keliru, sebab berlangsungnya suatu pendidikan dapat terjadi di sekolah. Sekolah adalah suatu lembaga pendidikan formal bagi sekelompok orang untuk menempa memperoleh ilmu pengetahuan tertentu demi kelangsungan hidup manusia, sehingga menjadi manusia yang baik dan berguna dalam hidup bermasyarakat berbangsa dan bernegara. 
Berlangsungnya proses pendidikan bukan terbatas pada lembaga pendidikan formal saja, namun menyangkutpengertian yang lebih luas yaitu pendidikan keluarga dan masyarakat. Pendidikan di dalam keluarga adalah merupakan tempat didapatkannya pendidikan yang pertama dan utama. Pendidikan masyarakat dan sekolah merupakan kelanjutan dari pendidikan yang diperoleh dalam keluarga. Ketiga tempat itulah merupakan wadah seseorang maupun sekelompok orang untuk memperoleh pengetahuan dan ilmu pengetahuan tertentu untuk bekal hidup. Menurut Ki Hajar Dewantara (dalam Dantes, 1999 : 4), seorang tokoh pendidikan taman siswa dan juga tokoh pendidikan nasional Republik Indonesia menyatakan pendidikan adalah sebagai daya upaya untuk mewujudkan tumbuhnya budi pekerti anak (kekuatan batin, karakter, pikiran atau intelek) dan tubuh anak itu untuk mewujukan kehidupan anak yang selaras dengan dunianya.

Manusia (anak) seperti yang tersebut di atas, sulit dicapai untuk era sekarang yang penuh dengan halhal yang mendegradasi sisi humanisme. Terlebih lagi pendidikan yang menurut Mu'in (2011: 21), seharusnya melahirkan manusia yang memiliki karakter baik, justru sebaliknya melahirkan manusia yang berprilaku buruk. Sentuhan psikologis jarang ditemukan dalam dunia pendidikan dewasa ini. Hal tersebut berakar pada diterapkannya pendidikan yang di dalamnya ada model dan proses tanpa menyentuh sisi humanisme itu sendiri, sehingga penerapan pendidikan hanya bersifat formalitas semata. Kekeringan ini yang menyebabkan manusia semakin jauh dari karakter manusia yang sesungguhnya, akibatnya lahirlah manusia-manusia yang cerdas secara jasmani namun kering secara rohani dan spiritual. Kekeringan akan sentuhan rohani akan mengakibatkan jiwa seseorang kosong. Dalam dunia pendidikan, kekeringan sisi rohani akan berdampak buruk pada pembentukkan karakter manusia. Manusia cenderung tumbuh menjadi manusia yang cerdas secara akal namun miskin secara spiritual. Banyak orang pintar, namun sedikit yang berkarakter.

Era global seperti sekarang ini, persoalan pokok yang dihadapi adalah bagaimana cara menyiapkan sumber daya manusia Hindu yang modern sekaligus berkarakter, dimana selalu tanggap terhadap perubahan yang ada di sekitarnya dan berusaha merealisasikan hasil pemikirannya, yakni perpaduan antara kognitif, afektif dan psikomotorik sehingga menghasilkan sebuah ide yang dinamis. Mewujudkan manusia-manusia yang unggul semacam ini tidak terlepas dari pada bagaimana pencetakan manusia semacam itu tercapai melalui pendidikan agama.

\section{PEMBAHASAN \\ II.1. Selayang Pandang Tentang Pendidikan Agama di Indonesia}

Bangsa Indonesia adalah bangsa yang religius, sikap hidup religius ini telah dimiliki oleh bangsa Indonesia sejak dahulu kala. Hal ini ditandai dengan adanya kepercayaan animisme, dinamisme yang berkembang di masyarakat Indonesia, kemudian masuknya agama Hindu dan Budha ke Indonesia diiringi dengan masuknya agama Islam, terakhir masuknya agama Kristen. ini membuktikan bahwa masyarakat 
Indonesia adalah masyarakat beragama. Fakta-fakta sejarah juga mendukung kenyataan ini. Dengan demikian tidak salah apabila dikatakan bahwa agama merupakan darah daging bagi masyarakat Indonesia. Oleh karena itulah para pendiri bangsa Indonesia sewaktu merumuskan dasar negara sepakat untuk mencantumkan asas "Ketuhanan Yang Maha Esa" sebagai salah satu asas dari Pancasila. Atas dasar ini, Bung Karno yang kemudian menjadi Presiden Pertama Republik Indonesia di depan Sidang Badan Penyelidik Usaha Kemerdekaan, pada tanggal 1 Juni 1945 mengatakan bahwa betapa pentingnya setiap bangsa Indonesia bertuhan dan mengajak setiap bangsa Indonesia.

Sesudah Indonesia merdeka, maka pada tanggal 18 Agustus 1945 ditetapkanlah Ketuhanan Yang Maha Esa sebagai sila pertama dari Pancasila. Esensi dari pencantuman asas ini bukanlah sesuatu pernyataan yang pasif akan tetapi mengandung arti pernyataan aktif. Maksudnya adalah jika negara telah menetapkan salah satu asasnya adalah Ketuhanan Yang Maha Esa, maka negara dan seluruh masyarakat Indonesia mesti proaktif untuk merealisasikan agar terwujud secara aktif makna Ketuhanan Yang Maha Esa itu. Perwujudan yang proaktif itu adalah antara lain :

1. Setiap masyarakat Indonesia mesti mengamalkan agamanya masingmasing.

2. Di dalam pengamalan tersebut masing-masing penganut agama diberi kebebasan sesuai dengan agama yang dianutnya.

3. Pemerintahan bertanggung jawab untuk memberikan kemudahan, fasilitas serta terwujudnya toleransi dalam mengamalkan ajaran agama masing-masing.

4. Pemerintahan dan masyarakat sama-sama bertanggung jawab terlaksanakannya pendidikan agama, baik formal maupun nonformal.

5. Semangat menjalankan agama masing-masing tersebut mesti direkat dengan semangat toleransi kehidupan beragama.

6. Pemerintah dan masyarakat samasama menjalin dan bertanggung jawab agar praktek-praktek kehidupan yang akan menggoncangkan sendi-sendi kehidupan beragama mesti dihindari.

Penjabaran yang telah dipaparkan di atas, tercantum pada asas Ketuhanan Yang Maha Esa yang dicantumkan pada Pancasila dan ditindaklanjuti dengan Undang-Undang Dasar 1945 sebagai landasan konstitusional. Dalam pembukaan Undang-Undang Dasar 1945 dicantumkan bahwa negara berdasar atas Ketuhana Yang Maha Esa menurut dasar kemanusiaan yang adil dan beradab. Atas dasar itu pula, maka di dalam batang tubuh Undang-Undang Dasar 1945 diatur hal yang berkenaan dengan ketuhanan, yakni pada Pasal 29 Ayat 1 dan 2 yang berbunyi :

Ayat 1 berbunyi : negara berdasar atas Ketuhanan Yang Maha Esa.

Ayat 2 berbunyi : negara menjamin kemerdekaan tiap- tiap penduduk untuk memeluk agamanya masingmasing dan beribadat menurut agama dan kepercayaan itu. 
Empat hal pokok yang menyebabkan agama memiliki peranan penting di Indonesia, yaitu :

1. Asas Ketuhanan Yang Maha Esa Permasalahan pokok disini adalah bagaimana menjadikan asas ini menjadi asas yang dinamis, bukan statis. Asas dinamis bahwa dituntut bagaimana supaya asas Ketuhanan Yang Maha Esa, aktif hanya pada tatanan filosofi dan pemikiran, tetapi dapat mencakup kepada pengamalan dalam kehidupan sehari-hari.

2. Asas Konstitusional Undang-Undang Dasar 1945

Batang tubuh UUD 1945, pada pasal 29 Ayat 1 dan 2. Ayat 1 disebutkan bahwa negara berdasar atas Ketuhanan Yang Maha Esa. Ayat 2 makna yang terkandung disini adalah bagaimana supaya setiap warga negara tersebut memiliki keyakinan dan kepercayaan terhadap Tuhan Yang Maha Esa, dan pada tahap berikutnya setiap pribadi tersebut menjalankan atau mengamalkan agamanya.

3. Kementerian Agama

Ketentuan yuridis menyebutkan bahwa Kementerian Agama adalah bagian dari integral dari Pemerintahan Negara Indonesia. Kementerian Agama merupakan sebuah lembaga yang mengurus masalah agama yang sudah pasti tidak semua negara memilikinya.

4. Kehidupan Sosial Religius Masyarakat Indonesia

Kehidupan beragama merupakan bagian yang tak terpisahkan dari kehidupan masyarakat Indonesia secara keseluruhan.
Merujuk pada kebijakan pemerintah seperti yang termaktub dalam rumusan GBHN tahun 1973, 1978, 1988 maupun GBHN tahun 1999 pendidikan agama mempunyai status yang lebih kuat. Dalam arah dan kebijaksanaan pembangunan umum bidang agama dan kepercayaan terhadap Tuhan Yang Maha Esa disebutkan sebagai berikut :

Diusahakan supaya terus bertambah sarana-sarana yang diperlukan bagi pembangunan kehidupan keagamaan dan kehidupan kepercayaan terhadap Tuhan Yang Maha Esa, termasuk pendidikan agama yang dimasukkan ke dalam kurikulum di sekolah-sekolah.

Berdasarkan pada kutipan rumusan GBHN di atas, tampak bahwa pendidikan agama dikehendaki agar menjadi pelajaran di sekolah dari tingkat dasar sampai di perguruan tinggi, sehingga tidak ada alasan lagi bagi anak untuk tidak mengikuti pendidikan agama.

Undang-undang Nomor 20 Tahun 2003 juga menguraikan tentang sistem Pendidikan Nasional yang menyatakan bahwa: (1) pendidikan agama dan keagamaan dapat diselenggarakan oleh pemerintah dan kelompok masyarakat dari pemeluk agama sesuai peraturan perundang-undangan yang ada, pendidikan agama berfungsi menyiapkan peserta didik menjadi masyarakat yang memahami dan mengamalkan nilai-nilai ajaran agamanya (Tanu, 2008: 3).

\section{II.2. Selayang Pandang Tentang Pendidikan Agama Hindu di Indonesia \\ Menurut Nurkancana (dalam Tanu, 2008 : 6) menguraikan bahwa pendidikan agama Hindu pertama}


kali disampaikan oleh rsi secara lisan dan bersifat turun temurun sehingga manusia mengenal tulisan. Oleh karena itu model pembelajaran agama Hindu yang dikembangkan adalah model pembelajaran upanisad yaitu duduk dekat kaki guru tunduk dan mengikuti perintah guru.

Pendidikan agama Hindu menurut Peraturan Pemerintah Nomor 55 Tahun 2007, menguraikan bahwa selain dilaksanakan di sekolah juga dapat dilaksanakan di luar sekolah, tujuannya adalah untuk meningkatkan pengetahuan dan pemahaman ajaran agama Hindu secara mendalam kepada seluruh umat Hindu. Selain itu hasil penanaman akhlak dan moral dapat diimplikasikan secara nyata oleh peserta didik dalam kehidupan beragama sehari-hari. Pendidikan agama Hindu yang diharapkan oleh masyarakat adalah pendidikan agama yang bersumber dan berakar kebiasan-kebiasaan yang terjadi di lingkungan keluarga kultur yang ada di masyarakat (Tanu, 2008 : 27).

Pendidikan agama Hindu menurut sastra-sastra agama Hindu seperti dalam Silakrama sering disebut dengan aguronaguron. Menurut Punyatmaja (dalam Sumaryana, 2007 : 14), menyatakan sebagai berikut :

Aguron-guron adalah masa menutut ilmu pengetahuan kerohanian di dalam sistem lapangan hidup kerohanian Hindu disebut Catur Asrama, yang berarti empat lapangan hidup berdasarkan petunjuk kerohanian yang terdiri dari brahmacari, grahasta, wanaprasta dan bhiksuka.
Aguron-guron atau asewake guru adalah suatu lapangan hidup atau asrama yang merupakan masa hidup dalam menuntut ilmu pengetahuan dan memupuk pribadi berkerohanian tinggi. Jadi dalam masa brahmacari, atau aguron-guron ini yang dipentingkan adalah dharma, karena dharma merupakan pedoman hidup bagi setiap orang untuk berbuat kebajikan. Setelah melewati masa brahmacari, barulah anak menginjak jenjang grehasta yaitu masa dalam membentuk rumah tangga yang bahagia, kemudian wanaprasta yaitu seseorang mengurangi kegiatan yang berhubungan dengan duniawi. Pendidikan agama Hindu juga diketengahkan dalam buku "Himpunan Keputusan Seminar Kesatuan Tafsir Terhadap Aspek-Aspek Agama Hindu$X V$ ", dimana isi buku ini bersumber dari hasil keputusan majelis tinggi agama Hindu yang menaungi dan membina kehidupan beragama Hindu. Berdasarkan buku ini dinyatakan bahwa pendidikan agama Hindu dibedakan menjadi dua jenis yaitu pendidikan agama Hindu di luar sekolah dan pendidikan agama Hindu di lingkungan sekolah. Pengertian kedua jenis pendidikan agama Hindu tersebut dijelaskan sebagai berikut :

1. Pendidikan agama Hindu di luar sekolah yaitu suatu upaya untuk membina pertumbuhan jiwa masyarakat dengan ajaran agama Hindu itu sendiri sebagai pokok materi. Tujuan pendidikan agama Hindu di luar sekolah adalah menanamkan ajaran agama Hindu itu menjadi keyakinan dan landasan segenap kegiatan umat Hindu dalam semua peri kehidupan; ajaran agama Hindu mengarahkan pertumbuhan 
tata kemasyarakatan umat Hindu serasi dengan Pancasila dasar negara Republik Indonesia; menyerasikan dan menyeimbangkan pelaksanaan bagian-bagian ajaran agama Hindu dalam masyarakat tattwa, susila dan yadnya; untuk mengembangkan hidup rukun antar umat baragama.

2. Pendidikan agama Hindu di sekolah yaitu suatu upaya untuk membina pertumbuhan jiwa raga anak didik sesuai dengan ajaran agama Hindu. Tujuan pendidikan agama Hindu di sekolah yaitu membentuk manusia Pancasila yang astiti bakti (bertaqwa) kepada Tuhan Yang Maha Esa; membentuk moral, etika, dan spiritual anak didik yang sesuai dengan ajaran agama Hindu (Parisadha Hindu Dharma Indonesia, 2001 : 2324; Sujana, 2000 : 53-55).

Sehubungan dengan hal itu pendidikan agama Hindu harus diupayakan agar terlaksana dengan baik berkesinambungan, sehingga tercipta keharmonisan hidup di dalam individu umat itu sendiri, intern umatberagama serta antar umat beragama dalam mewujudkan kedamaian hidup. Pentingnya pendidikan agama Hindu tersebut dalam kitab suci Veda dijelaskan sebagai berikut.

Aksetravit ksetravidam

hyaprat

sa paiti ksetravidānuśistah

etad van bhadram

anuśāsanasyo

ta sruti vindatyas ñjasinām

(Rgveda, X. 32. 7)
Terjemahan :

Orang yang tak mengenal

suatu tempat bertanya kepada

orang yang mengetahuinya.

Ia meneruskan

perjalanan,dibimbing oleh

orang yang tahu. Inilah

manfaat pendidikan. Ia

menemukan jalan yang lurus

(Titib, 1996:

249).

Demikian pentingnya pendidikan agama Hindu dalam menjalankan kewajiban hidup di dunia bagi anak. Anak yang tidak berpendidikan (pendidikan agama Hindu) akan avidya yaitu tidak ada sesuatu yang berarti yang bisa dilakukannya, malahan akan dilecehkan dan dijauhi oleh orang-orang sekitarnya. Usaha-usaha untuk mempelajari sastra agama Hindu adalah suatu yang utama di dalam mengamalkan ajaran agama melalui pendidikan agama Hindu, sehingga menjadi anak yang berguna di tengah-tengah masyarakat.

\subsection{Identifikasi Masalah Kebutuhan Pendidikan Agama Hindu}

Pendidikan agama Hindu yang berlangsung dan berjalan dalam dekade waktu sampai detik ini ternyata masih tetap memiliki ketidaksempurnaan, dimana ditandai dengan adanya berbagai macam permasalahan yang menyertai proses perjalanan pendidikan agama Hindu. Adapun identifikasi masalah dalam pendidikan agama Hindu yang dapat penulis kemukakan adalah sebagai berikut : 
1. Pendidikan agama terutama pendidikan agama Hindu menjadi pendidikan yang dinomorduakan dan kurang penting, sehingga dianggap remeh maupun dikesampingkan dibandingkan pelajaran yang lainnya (kebutuhan terkait prestise atau penghargaan terhadap eksistensi lembaga pendidikan agama Hindu).

2. Materi pendidikan agama Hindu oleh anak dianggap membosankan dan kurang menarik.

3. Anak saat mengikuti proses belajar mengajar dalam pendidikan agama Hindu cepat merasa bosan dan jenuh (kebutuhan terkait situasi yang menyenangkan dan nyaman anak saat mengikuti pendidikan dan pengajaran).

4. Situasi pada proses belajar mengajar agama Hindu sering pasif.

5. Penilaian atau evaluasi dalam pelajaran agama Hindu pada pendidikan agama Hindu dianggap kabur.

6. Output dari pendidikan agama Hindu secara kognitif-afektif-psykomotorik masih kurang (rendah).

7. Outcome dari pendidikan agama Hindu kurang mampu bersaing di dunia luar (kehidupan seharihari dan persaingan kerja) (kebutuhan aktualisasi diri dan mempertahankan diri).

8. Pendidikan agama Hindu kurang mampu memberikan perubahan yang signifikan pada anak. Hal ini terlihat dari maraknya perilaku menyimpang yang dilakukan oleh anak (tawuran pelajar, tindak kekerasan, pencurian, seks bebas, narkoba, dan lain-lain).
9. Beberapa anak Hindu di luar Bali yang bersekolah di lembaga- lembaga pendidikan non Hindu, masih memperoleh ketidakadilan dalam mengenyam pendidikan agama. Mereka terpaksa mengikuti program pendidikan agama agama yang ditetapkan oleh sekolah tersebut.

10. Basis pendidikan agama Hindu yang dimiliki oleh umat Hindu sampai detik ini jumlahnya minim, berbeda dengan agama lain seperti Islam memiliki banyak basis pendidikan agama Islam yang tersebar di seluruh pelosok Indonesia dari taman kanakkanak sampai perguruan tinggi.

11. Alokasi biaya pendidikan untuk pendidikan agama Hindu minim.

\subsection{Identifikasi Sumber Masalah Kebutuhan Pendidikan Agama Hindu}

1. Pendidikan agama terutama pendidikan agama Hindu menjadi pendidikan yang dinomorduakan dan kurang penting, sehingga dianggap remeh maupun dikesampingkan dibandingkan mata pelajaran yang lainnya (Kebutuhan terkait prestise atau penghargaan terhadap eksistensi lembaga pendidikan

agama

\section{Hindu).}

Hal ini terjadi bersumber dari bagaimana pemerintah dan pakar ahli di bidang pendidikan terutama dalam hal ini terkait pendidikan agama Hindu di dalam membuat dan menerapkan atau aplikasi kebijakan pendidikan. Kebijakan ataupun aturan dalam dunia pendidikan khususnya pendidikan agama Hindu terlihat didominasi oleh pusat tanpa 
memperhatikan aspirasi daerah. Dominasi birokrasi kekuasaan dalam penentuan kebijakan pendidikan agama Hindu pun sangat kental, mengingat agama Hindu adalah minoritas.

2. Materi pendidikan agama Hindu oleh anak dianggap membosankan dan kurang menarik.

Hal ini terjadi bersumber dari bagimana mengkemas materi pendidikan agama Hindu agar menarik, menyenangkan, inovatif, kreatif, intelektual dan religius sehingga materi agama Hindu tidak membosankan kurang menarik. Materi pendidikan agama Hindu yang dikembangkan dan disampaikan oleh pendidik/guru lebih banyak masih bersifat monoton teoretik (ceramah materi). Beberapa diantara pendidik atau guru yang mengajar dan mendidik agama Hindu pada anak kurang memahami materi yang ada maupun kemampuan dan keterampilan mengembangkan materi pembelajaran yang kurang. Media penunjang penyampaian materi pendidikan agama Hindu kadangkala kurang memadai.

\section{Peserta didik saat mengikuti proses belajar mengajar dalam pendidikan agama Hindu cepat merasa bosan dan jenuh (kebutuhan terkait situasi yang menyenangkan dan nyaman anak saat mengikuti pendidikan dan pengajaran).}

Hal ini bersumber pada materi pendidikan agama Hindu yang disampaikan dan dikembangkan oleh pendidik/guru kurang memperhatikan kebutuhan anak berdasarkan tingkat pertumbuhan dan perkembangan anak.
Anak dibebankan materi pendidikan agama Hindu yang selalu mengarah vertikal (dunia abstrak), hal ini karena pendidik/gurukadangkalalupamengaitkan materi pembelajaran agama Hindu dengan konteks kehidupan nyata (dunia kongkrit/ nyata). Ini mengindikasikan pendidik/guru hanya sekedar menyampaikan materi atau hanya transfer knowledge, tanpa adanya pengaitan aplikasi pada kehidupan sehari- hari atau transfer value. Pendidik/ guru dalam pendidikan agama Hindu masih menggunakan metode, model ataupun pola pembelajaran konvensional.

\section{Situasi kelas pada proses belajar mengajar agama Hindu sering pasif.}

Hal ini bersumber pada kemampuan dan keterampilan seorang pendidik/guru dalam mengoptimalkan seluruh komponen yang ada dalam proses belajar mengajar, baik itu komponen isi pendidikan (kurikulum, materi pembelajaran, alokasi waktu), komponen sarana dan prasarana dan pembelajaran, komponen manusia pembelajar yaitu pendidik dan anak harus berlangsung dua arah serta memahami karakteristik fisik dan psykis yang menjadi hakikat dasar manusia dalam pendidikan.

\section{Penilaian atau evaluasi dalam pelajaran agama Hindu pada pendidikan agama Hindu dianggap kabur.}

Penilaian atau evaluasi pada pendidikan agama Hindu selama ini menggunakan rasa bukan alat ukur yang valid. Mengingat pendidikan agama adalah menyangkut rasa keyakinan atau kepercayaan terhadap tuhan, sering kali disalah persepsikan bahwa 
dalam mengevaluasi atau menilai tidak ada alat ukur yang bias mengukurnya sehingga rasalah yang mendominasi penilaian tersebut. Disamping itu pula ada argumentasi bahwa pendidikan agama yang begitu mudahnya, masak mendapatkan nilai yang rendah. Oleh karena itu dapat dilihat bagaimana hasil evaluasi atau penilaian terhadap pendidikan agama Hindu yang diperoleh oleh anak pasti rata-ratanya tinggi antara 9 dan 10.

\subsection{Alternatif Pemecahan Masalah Kebutuhan Pendidikan Agama Hindu}

Berbicara alternatif pemecahan masalah pendidikan terutama pendidikan agama Hindu memang agak susah, karena masalah pendidikan yang ada cukup kompleks. Usaha untuk memberikan alternatif pemecahan masalah pendidikan terutama pendidikan agama Hindu berdasarkan permasalahan yang ada secara umum sebagai berikut :

Kondisi masyarakat Indonesia yang heterogen dengan berbagai macam keragaman budaya, adat, suku, sumber daya alam, dan bahkan sumber daya manusia. Masing-masing daerah memiliki kesiapan dan kemampuan yang berbeda dalam pelaksanaan kurikulum atau bahan ajar ataupun hal lainnya yang tertuang dalam pendidikan agama Hindu yang ditetapkan sebagai sebuah desentralisasi pendidikan. Hal ini memicu terciptanya tidak relevannya pendidikan agama Hindu dengan kondisi daerah. Konteks pelaksanaan otonomi daerah ditegaskan bahwa sistem pendidikan nasional yang bersifat sentralistis selama ini kurang mendorong terjadinya demoktarisasi dan desentralisasi penyelenggaraan pendidikan termasuk pendidikan agama Hindu. Sistem pendidikan yang sentralistis diakui kurang bisa mengakomodasi keberagaman daerah, keberagaman sekolah, keberagaman peserta didik (anak), bahkan cenderung mematikan partisipasi masyarakat dalam pengembangan pendididikan termasuk dalam hal ini pada pendidikan agama Hindu. Oleh karenanya perlu adanya kesadaran bersama semua pihak atau komponen baik itu pemerintah, pihak yang berkecimpung dalam dunia pendidikan dan masyarakat untuk ikut serta dalam rangka merencanakan, melaksanakan, mengawasi dan mengevaluasi pendidikan agama Hindu yang berlangsung sehingga pendidikan agama Hindu yang diharapkan berdasarkan konstitusi agama dan konstitusi negara dapat berjalan selaras, serasi dan seimbang mewujudkan tujuan dari pendidikan agama Hindu tersebut.

Mengingat agama Hindu mayoritasnya di Bali, maka masyarakat Bali sebagai penganut umat Hindu dalam praktek kehidupan sehari-hari harus berupaya mensinergikan pendidikan agama Hindu dalam tradisi kefilsafatan, budaya dan sekaligus agama dalam suatu bentuk manifestasi kebudayaan HinduBali. Wujud kebudayaan yang muncul dalam masyarakat Bali merupakan suatu bentuk kebudayaan yang didalamnya mengandung suatu bentuk kefilsafatan dan ajaran agama, hal inilah yang harus tertuang dalam sistem pendidikan dan pendidikan agama Hindu. Jangan sampai pendidikan agama apalagi pendidikan agama Hindu di Bali mengaburkan ataupun menghilangkan nafas keHinduannya serta kebudayan local genius di Bali. Perlu juga 
diperhatikan adanya pendidikan agama Hindu yang berbasis dari Taman Kanakkanak sampai perguruan tinggi seperti gagasan keberadaan pendidikan agama Hindu yang sering disebut dengan nama pasraman.

1. Untuk Taman Kanak-Kanak (TK) disebut Pra Widya Pasraman dialokasikan satu ruang belajar dan tempat bermain anak-anak.

2. Tingkat Sekolah Dasar (SD) disebut Adi Widya Pasraman perlu dialokasikan enam ruang belajar, satu ruang untuk para guru dan satu ruang untuk perpustakaan.

3. Untuk tingkat Sekolah Menengah Pertama disebut Madyama Widya Pasraman perlu dialokasikan tiga ruang belajar, satu ruang untuk para guru dan satu ruang untuk perpustakaan dan laboratorium.

4. Untuk Sekolah Menengah Atas (SMA) disebut Utama Widya Pasraman perlu dialokasikan enam ruang yaitu untuk kelas I, II dan III masing-masing satu ruang, tiga ruang lagi untuk guru, ruang TU dan ruang perpustakaan (Tim Penyusun, 2006:19; Titib, 2003: 123).

Hal ini tentu akan mengembangkan secara kuantitas sekolah berbasis agama Hindu ke depannya untuk umat Hindu, akan tetapi tetap pula harus didukung oleh kualitas yang baik. Pelaksanaan pendidikan agama Hindu juga harus memperhatikan :

1. Tersedianya tenaga pengajar (guru) yang kompeten

2. Tersediannya fasilitas fisik atau fasilitas belajar yang memadai dan menyenangkan.
3. Tersedianya fasilitas bantu untuk proses belajar mengajar.

4. Adanya tenaga penunjang pendidikan, seperti tenaga administrasi, pembimbing, pustakawan laboran.

5. Tersedianya dana yang memadai dalam hal ini termasuk beasiswa bagi peserta didik (anak) atau sekolah gratis (dengan ketentuan yang tepat).

6. Manajemen yang efektif dan efisien.

7. Memiliki alat evaluasi yang baik dan tepat

8. Terpeliharanya budaya yang menunjang seperti nilai-nilai religius, moral, kebangsaan dan lain-lain.

9. Kepemimpinan pendidikan yang visioner, transparan dan akuntabel.

Materi yang diberikan selama proses pendidikan agama Hindu meliputi :

1. Pembinaan budi pekerti

Materi yang disajikan adalah materi yang menyangkut budi pekerti yang digali oleh pendidik/guru bersumber dari ajaran agama Hindu serta kearifan lokal yang berlaku. Pada prinsipnya dapat membentuk sikap mental dan perilaku yang menunjukkan kepribadian masyarakat Hindu yang beragama Hindu yaitu sikap ramah, sopan dan ngadap kasor.

2. Etika/ tata karma

Materinya digali dari pustaka-pustaka Hindu yang memuat tentang tata karma dan kearifan lokal masyarakat Hindu menyangkut tata karma berbicara dengan orang tua, dengan teman sebaya, dengan sulinggih dan saat ada pertemuan, selain itu juga diajarkan tentang tata busana (menghadiri acara apa, dimana dan apa) agar anak dapat mengetahui tata berbusana karena hal 
ini akan menunjukkan etika/sopan santun seseorang.

3. Pembinaan Dharmagita

Dharmagita yang dilatih hendaknya diutamakan keterampilan makidung karena kidung selalu dipergunakan pada setiap upacara agama apalagi pada saat dilakukan upacara persembahyangan agama Hindu.

4. Melatih yoga asanas

5. Keterampilan membuat sarana upacara

Pelaksanaan kegiatan ini disesuaikan dengan situasi dan kondisi setempat, karena istilah penyebutan sarana upacara/upakara serta bentuknya biasa berbeda-beda di masing-masing tempat jadi disesuaikan dengan local genius masing-masing tempat.

6. Bercerita dan dharmatula

Kegiatan ini dimaksudkan untuk memberikan pemahaman pada anak tentang benar dan salah, baik dan buruk. Sebab dengan bercerita anak dapat mempersonifikasikan dirinya serta turut ambil bagian menyimak dan meresapi inti cerita, sehingga dengan bercerita penanaman nilai- nilai moral etika bernuansa Hindu lokal akan saat efektif.

7. Karya wisata/ mengenal salah satu pura terdekat

Kegiatan ini dimaksudkan agar siswa dapat mengenal secara kongkrit apa yang ada dan terjadi di lingkungan sekitarnya apalagi agama Hindu dengan kebudayaan Hindu. Hal ini akan memantapkan pemahaman anak terhadap agama bernuansa kebudayaan Hindu serta akan membawa kesan yang mendalam bagi anak yang akan dapat diingat dalam kurun waktu yang lama (Ngurah, 2010 : 6-9).

Pelaksanaan kurikulum dan materi pendidikan agama Hindu oleh pendidik/ guru harus berlandaskan pada enam (6) hal ini yaitu :

1. Dasar ontologis, dimana pendidik/ guru harus mengetahui dan memahami secara sungguh-sungguh fokus atau substansi masing-masing materi agama Hindu untuk diajarkan kepada anak.

2. Dasar semantik, dimana pendidik/ guru harus mampu membahasakan kebenarannya dengan bahasa yang dapat dipahami oleh anak, sehingga setiap topik atau substansi atau materi agama Hindu yang disampaikan kepada anak tidak mengalami kehilangan makna.

3. Dasar epistemologis, dimana pendidik/guru harus mampu mentrasformasikan, mengembangkan dan mencari strategi-strategi baru dalam pembelajaran agama Hindu agar anak dapat memahami materi dengan mudah dan benar.

4. Dasar aksiologis, dimana pendidik/ guru harus mampu menjelaskan dan mensugesti anak akan pentingnya materi agama Hindu yang dipelajari serta kemanfaatannya bagi kehidupannya kelak.

5. Dasar metodologis, dimana pendidik/ guru harus memahami bagaimana prosedur dan metode mempelajari substansi pembelajaran agama Hindu dan bagaimana pula mengembangkan pengetahuan agama Hindu yang relevan dengan substansi itu. 
6. Dasar etika, dimana pendidik/ guru harus mampu memahami dan memaknai tentang bagaimana pertimbangan moral menghadapi realitas keseharian dikaitkan dengan substansi pelajaran agama Hindu dan kehidupan pada umumnya. Disini, pendidik/guru pun harus mampu meyakinkan anak bahwa substansi materi agama Hindu yang dipelajari dan cara mempelajari atau mengajarkannya tidak bertentangan dengan etika dan moral.

Model pembelajaran yang digunakan dalam pendidikan agama Hindu dapat merujuk konsep Sad Dharma yaitu meliputi :

\section{Dharma Tula}

Kata tula dalam bahasa Sansekerta artinya perimbangan atau keserupaan atau bertimbang. Secara harfiah dharmatula artinya bertimbang wirasa atau berdiskusi. Dharmatula sering dilaksanakan pada saat perayaan hari raya Saraswati, Siwalatri, kegiatan seminar, simposium, Lokasabha, Mahasabha hal ini bersifat terbatas. Hal ini dapat dicermati jika Dharmatula itu sudah mulai dilaksanakan pada jenjang pendidikan formal tentu akan bermanfaat.

\section{Dharmawacana}

Metode pembelajaran atau penerangan agama Hindu yang dapat dipakai mendeskripsikan materi pembelajaran agama Hindu kepada anak.

\section{Dharmagita}

Nyanyian tentang dharma dan atau dharma. Nyanyian tentang dharma maksudnya ajaran-ajaran agama Hindu dikemas dalam bentuk nyanyian spiritual yang bernilai ritus sehingga yang menyanyikan dan yang mendengarkan samasama dapat belajar menghayati serta memperdalam ajaran dharma.

\section{Dharma Yatra}

Usaha meningkatkan pemahaman dan pengalaman pembelajaran agama Hindu melalui persembahyangan langsung ke tempat-tempat suci, selain itu anak memperoleh pengalaman tentang apa yang sudah dipelajari secara teoretis di kelas sekaligus nantinya diharapkan dapat dipadukan antara pembelajaran teoritis dan proses pembelajaran praktis.

\section{Dharma Sadhana}

Metode pembelajaran agama Hindu dengan upaya pembinaan dan pembiasaan dalam bentuk praktek ajaran dharma.

\section{Dharma Santi}

Kegiatan dharma dalam rangka mengkondisikan kehidupan rukun, damai, tentram dan sejahtera dengan bernuansa lokal genius.

\section{PENUTUP}

Pendidikan agama Hindu dengan nuansa kebudayaan Hindu mempunyai tanggung jawab yang cukup berat dalam usaha menciptakan anak yang cerdas, terampil, beriman dan bertaqwa sehingga membentuk kepribadian anak yang luhur seperti disebutkan dalam Kitab Suci Hindu dan Undang-Undang Sistem Pendidikan. Untuk itu lembaga-lembaga yang menangani tentang pendidikan baik informal, formal dan nonformal sebagai penanggung jawab dalam sistem pendidikan agama Hindu, harus berusaha menciptakan sistem yang selain demokratis, juga mempersiapkan dengan 
kebijakan-kebijakannya yang akan memperlebar ruang gerak pendidikan agama Hindu ditunjang dengan kajian ilmiah kritis tentang pemilihan materimateri yang sesuai, juga tenaga pengajar sebagai perisai keberhasilan pendidikan agama Hindu dengan tetap berpegang pada landasan berpijak (berakar pada) yaitu nilai-nilai Hindu yang telah ada yang disesuaikan dengan perkembangan yang ada.

\section{DAFTAR PUSTAKA}

Adiputra, I Gede Rudia. 2004. Dasardasar Agama Hindu. Jakarta : Direktorat Jenderal Bimbingan Masyarakat Hindu dan Buddha Departemen Agama RI.

Dantes I Nyoman, 1999. Teori-Teori Belajar, Teori-teori Instruksional dan Model-Model Pembelajaran, Singaraja : STKIP Negeri Singaraja. Jalaludin. 2003. Teologi Pendidikan. Jakarta: PT Raja Grafindo Persada.

Mudyahardjo, Redja. 2001. Pengantar Pendidikan. Jakarta : PT Raja Grafindo Persada.

Mu'in, Fatchul. 2011. Pendidikan Karakter Kontruksi Teoritik dan Praktik. Jogjakarta : Az-Ruzz Media.

Ngurah, I Gusti Made. 2010. Pedoman Pelaksanaan Pasraman Kilat. Denpasar : kanwil Kementerian Agama Provinsi Bali.

Punyatmadja, Ida Bagus Oka. 1992. Çilakrama. Upada Sastra.

Sandika, I Ketut. Pendidikan Menurut Veda. 2011. Denpasar : Pustaka Bali Post.
Sujana, I Made dan I Nyoman Susila. 2000. Manggala Upacara. Depertemen Agama Republik Indonesia.

Tanu,I Ketut. 2008. Isu-Isu Kontemporer Pendidikan agama Hindu Di sekolah Dasar (Perspektif Pendidikan Agama Hindu). Denpasar : Sari Khayangan Indonesia.

Titib, I 2003. Menumbuhkembangkan Pendidikan Budhi Pekerti Pada Anak (Perspektif Agama Hindu). Jakarta : Ganeca Exact.

Titib, I Made. 1996. Weda Sabda Suci Pedoman Praktis Kehidupan. Surabaya : Paramita.

Tim Penyusun, 2006. Pedoman Pengelolaan Pasraman. Surabaya : Paramita. 2001. Himpunan Kesatuan Tafsir Terhadap Aspek-aspek Agama Hindu $I-X V$. Denpasar : Parisada Hindu Dharma Indonesia.

Undang-Undang Dasar 1945

Undang-Undang Nomor 20 Tahun 2003 tentang Sistem Pendidikan Nasional. Wiana, I Ketut. 2000. Cara Belajar Agama Hindu yang Baik. Denpasar:

Yayasan Dharma Naradha. 